\title{
Songs by Adam Fehti
}

Translated by Hager Ben Driss

Université de Tunis

\section{Introduction}

Fathi Guesmi, better known by his pen name Adam Fethi was born on October 3rd, 1957. He is one of the most celebrated leftist writers in Tunisia and his politically engaged poetry is highly popular among students. Writing under the siege of political oppression in the 1970s and 1990s, several of his poems were banned. He wrote songs to several committed groups such as Al-Babth al-Musiqi ("Music Research") and Awled al-Manajim ("Children of the Mines"). His poems are also sung by such famous artists as Tunisian Lotfi BouChnak and Lebanese Marcel Khalifa. He is the author of Ughniat al-Naqabi al-Fasih (Song of the Eloquent Unionist, 1986), Anachid li Zahrat al-Ghubar (Songs to the Dust Rose, 1992) and Nafikhu al-Zujaj al-A'maa (The Blind Glassblower, 2011), which won the prestigious Abou Kacem Chebbi Prize.

Fethi claims that "the song is as powerful and extraordinary"1 as any other literary text. His repertoire of songs includes texts written in Tunisian dialect as well as standard Arabic. Both "Tell Me About Your Dreams" and "Living for My Songs" are written in Tunisian dialect and address two subjects often reiterated in Fethi's songs. Indeed, The poet's dream of a free and democratic country infiltrates all his poetic texts. The dream turns out to be a mode of resistance. The second song represents a meta-poetic moment, if we can venture to use this phrase imitating meta-fiction. The song is selfreflexive; it mirrors the poet's lifelong devotion to songs as well as his anxieties over a misunderstanding and belittling of this artistic genre. The two other songs, "Coming Back to you" and "I'll Take My Face and Leave" are written in standard Arabic and differ in register. The first is a love song; the second is highly political.

1 Interview by France Culture. 9 July 2012. https://www.franceculture.fr/emissions/la-poesie-nest-pas-unesolution/adam-fathi-tunisie 
Writing songs translates Fethi's belief in bringing poetry to everyday life. A poem should be consumed by everybody, and not restricted to a closed circle of intellectuals. He finds in the song an apt medium to reach a large audience with different musical tastes. "I'll Take My Face and Leave", for instance, is set to a simple melody with only the lute as a musical instrument ${ }^{2}$. The aim is to give the greatest space possible to the word. While this type of music attracts mainly students, another audience has a predilection for the large number of Fethi's poems composed and sung by Lotfi Bouchnak. "Living for my Songs" offers an interesting case of transnational art, as Bouchnak uses Chopin's "Etude Op. 10 No. 3" to sing in a fluid way a poem written in Arabic ${ }^{3}$.

If Tunisian dialect is my mother tongue, standard Arabic is my first language and therefore there is no difference translating from both. Actually, Fethi's songs written in Tunisian language are as beautiful and powerful as those written in the standard one. The most challenging venture was to recreate the musicality of these texts. I had to choose one option: either a close translation wherein I ignore the rhyme patterns of the songs or a creative one wherein I keep the spirit of the songs and their music. I opted for a rather creative translation while trying to recreate the songs by imitating the rhyming patterns of the original texts. To achieve that, I had to work on images not words. A literal translation yields insipid texts, a mere cluster of words. Here is an illustrative example from the third and fourth lines of "Tell Me About Your Dreams": the literal translation gives: " There are dreams that burrow/ in a wound that doesn't heal." I opted for a domestication strategy by opting for an English idiom, "turn the knife in the wound", which captures the meaning of suffering expressed in the two lines.

\footnotetext{
${ }^{2}$ Link to the song: https://www.youtube.com/watch?v=TkG8iYRrUbs

${ }^{3}$ Link to the song: https://www.youtube.com/watch?v=Ps2wsGYh qk 


\section{Tell Me About Your Dreams}

There are dreams that live and then over time peel.

There are dreams that turn the knife in wounds difficult to heal.

There are those lingering behind

in our dark recess

and those who always outstrip

us in their progress.

There are dreams that diverge and dreams that converge, those that bring joy to the bleakest dirge, those that spin a story out of a dream wool, those that steal us inside out and spoil our story to the full.

There are faithful dreams that remember dear old friends, there's a treacherous kind whose betrayal never ends.

There are those that hide us inside we catch up with them when we're left behind and those that from us hide we keep seeking them and never find

There are dreams that grow large the way ambitions grow.

There are those that grow old, wither, and lose glow. 
Ones that become tired when mature, others that tire you when obscure, ones that put years on you when unsure, others that fail you when they lose allure.

There are dreams that torture the pursuers, and dreams that only torture the doers.

There are dreams that elevate, make a tree out of a seed, and those that destroy, cultivate hatred and never concede.

There are dreams that fade, dreams that cannot be staid, ones if ever weighed become difficult to carry. There are those that lurk, those we erase, those ready to burke those that leave no trace those that bring back the best days confront us with the tough query: what have we done with our dreams?

I, for a long time beam nestled in a dreamy gleam, can no longer distinguish between memory and dream. 


\section{Living for my Song}

Living for my song, living for people, living like my song anything in my heart spills on my tongue, and anything I own goes to people ...

Words hurt, songs soothe

I'm, since my early youth, living for my song living for people, living like my song anything in my heart spills on my tongue, and anything I own goes to people ...

Don't ask why I sing.

Maybe the song will take me away to a new day whose sun will open the door and laughter will roar; our life becomes a holiday ...

The journey reminds me of the miles ahead, of those who aged early and those who were dead, of gridded windows in people's eyes, of fire I crossed with a heart that fries.

My soul asks me: have you achieved anything?

Ah! That cruel question of the soul ...

It's true I sang to the wind, but it's enough for my song to sweep my people's tears.

It's enough for my song to take the road without a break ... It's enough for your streets afar, full of tears and many a scar, to see me living, holding a song, a candle telling a story, a story burning, dreaming of a new morning. And I'm living for my song living for people, living like my song 
anything in my heart spills on my tongue, and anything I own goes to people ...

Don't ask why I sing.

Maybe the song will take me away

to a new day

whose sun will open the door

and laughter will roar;

our life becomes a holiday ...

(Music: Chopin, "Etude Op. 10 No. 3"

Singing: Lotfi Bouchnak)

\section{Coming Back to You}

With the morning's desire for your lips, With the rose's fragrance on your face, I come back to you, for how to eclipse all the roads that show but your trace.

Before me, the city sleeps and gets empty.

I go out in a night silent and jetty.

I watch nocturnal cats alert and stretchy looking for warmth in your space.

I call them; they yield only to turn snubby.

Like me, they escape you while seeking your place.

$*$

Like songs, years tick away

before eyes never looking my way.

years tick away, I in my place stay

like some dust on your shoulders plays.

I wake up in my time, stranger and stray

and snatch my soul from you in your embrace.

(Composition: LotfiBouchnak.

Singing: Alia Bel Eid) 


\section{I'll Take my Face and Leave}

I'll take my face and leave when death calls, storming like the wind, flaming like a field burned with a wound.

I'll take my face and leave.

I'll take my face and leave, shrouded in songs and memories.

So save my skin and cane for the child who shall grow up and reign.

I'll take my face and leave.

I'll take my face and leave.

But back I shall come

with anger beating on a drum, with a huge jump taking me home.

I'll bring my face back riding a song telling birds never fear a wound telling palm trees and oranges newly born let's build a land in the new morn let's build a land in the new morn.

(Composition: Nibras Chammam Singing: Amel Hamrouni \&Abir Chammam) 
قل لي شنيّة احلامك

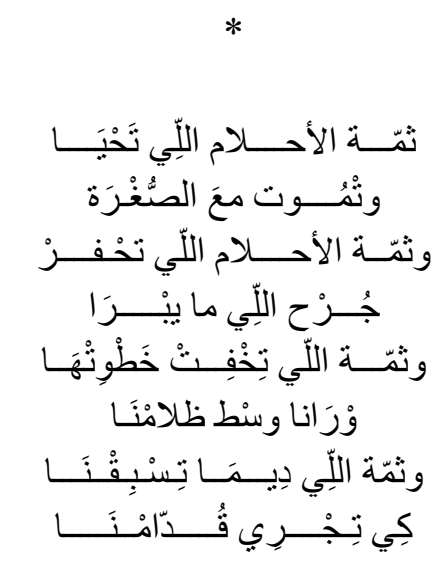

$*$

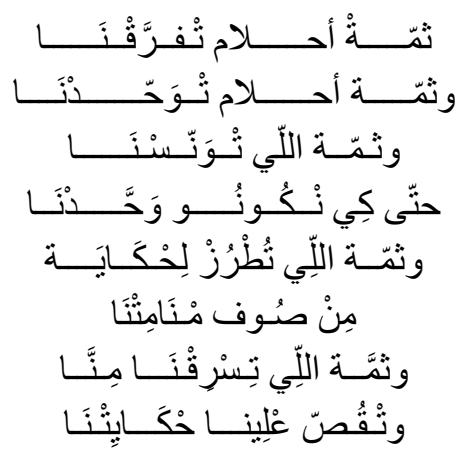

$*$

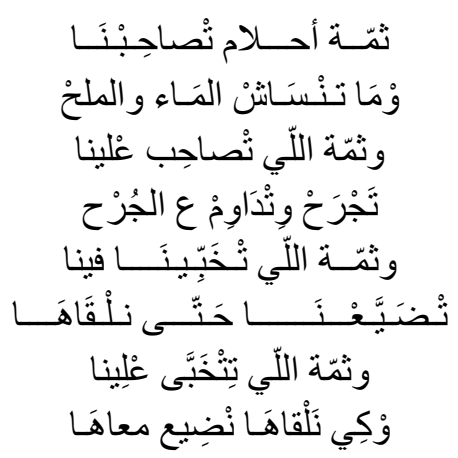

$*$ 


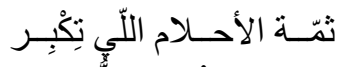

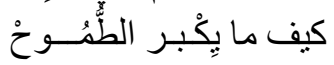

$$
\begin{aligned}
& \text { وثمّـــة اللّي تكبر في السنّ } \\
& \text { تهرم كي جسم بلا روح فئس فئ }
\end{aligned}
$$

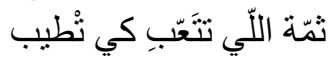

$$
\begin{aligned}
& \text { وثمّة اللي تتعب كي تغيب } \\
& \text { وثثمّة اللّي تشيّب كي تخيب } \\
& \text { وثمّة اللي تخيّب كي نُشيب لنيب }
\end{aligned}
$$

$*$

$$
\begin{aligned}
& \text { ثمّة الأحلام اللِّي تُعذبّب } \\
& \text { اللّي يجري ور اها }
\end{aligned}
$$

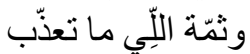

$$
\begin{aligned}
& \text { كان اللِّي يقدْر يَحْيَاهَا }
\end{aligned}
$$

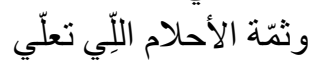

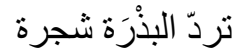

$$
\begin{aligned}
& \text { وثمّة اللّي تهدّم وتخلّّي }
\end{aligned}
$$

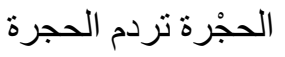

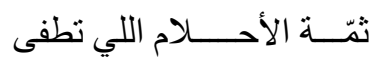

$$
\begin{aligned}
& \text { وثمّة اللي تتعب م الوقفة }
\end{aligned}
$$

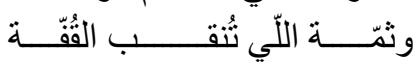

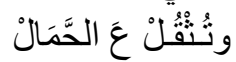

$$
\begin{aligned}
& \text { وثمّة اللي تتخبّى ور انا } \\
& \text { وثمّة اللي ننساها } \\
& \text { وثمّة اللي تتسانا } \\
& \text { وثمّة الاحلام اللي تمشي وتخلينا ور اها } \\
& \text { وثمّة اللي تتخبّى ور انا } \\
& \text { وثمّة اللي تذكّرنا باحلى ايّامنا } \\
& \text { وتُقتلنا كي تو اجهنا بالسؤ ال: } \\
& \text { شَعْلنَا بأحلامنا } \\
& \text { و انا اللّي في حُضْن احلامي } \\
& \text { عايشن طُول حياتي }
\end{aligned}
$$




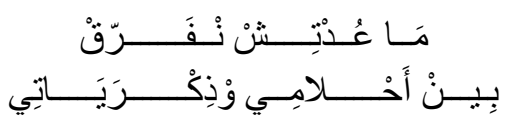

شعر آدم فتحي

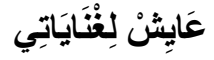

$$
\begin{aligned}
& *
\end{aligned}
$$

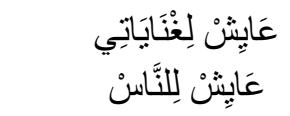

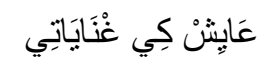

$$
\begin{aligned}
& \text { اللِي في قَلبي على لُنَتَانِي } \\
& \text { و اللِّي عِنْدِي للِنَّاسْ... }
\end{aligned}
$$

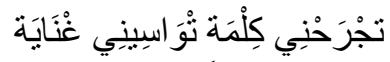

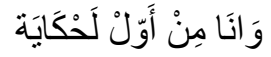

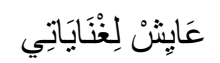

$$
\begin{aligned}
& \text { عَانِشْن لِلْنَّاسن }
\end{aligned}
$$

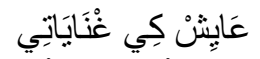

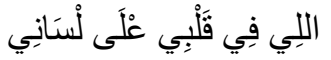

$$
\begin{aligned}
& \text { و الالِي عِنْدي لِلنَّاسن.. }
\end{aligned}
$$

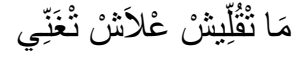

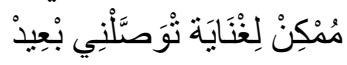

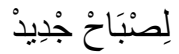

$$
\begin{aligned}
& \text { شَمَسْهُه تُجِلَ الَبَابْ }
\end{aligned}
$$

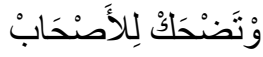

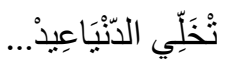

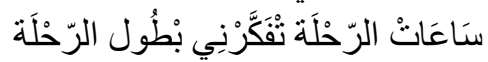

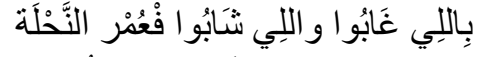

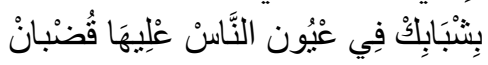

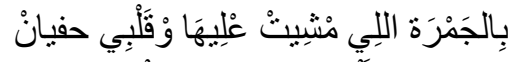

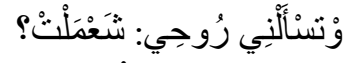

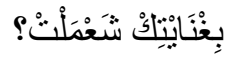

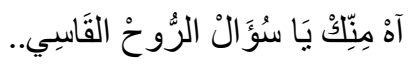

$$
\begin{aligned}
& \text { أنا صنحِيخ }
\end{aligned}
$$

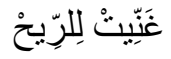

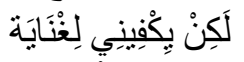

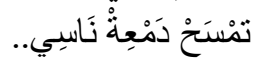

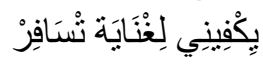




$$
\begin{aligned}
& \text { فِي طُرِيقُ مَا عندُوُشِيَ آخِرْ... }
\end{aligned}
$$

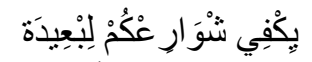

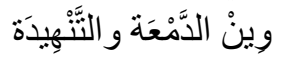

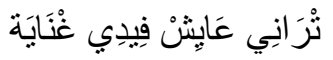

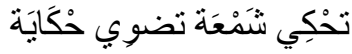

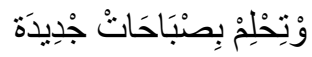

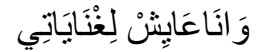

$$
\begin{aligned}
& \text { عَاِيشن لِلنَّاسن } \\
& \text { عَاِِشن كِي غْنَايَاتِتِي }
\end{aligned}
$$

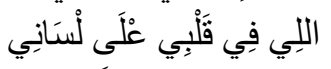

$$
\begin{aligned}
& \text { و اللِي عِنْدِي للِنَّاسن.. }
\end{aligned}
$$

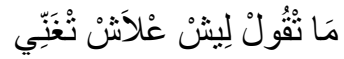

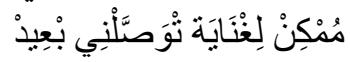

$$
\begin{aligned}
& \text { لِلصنبَاحْ جُدِيدْ }
\end{aligned}
$$

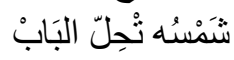

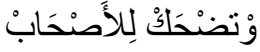

$$
\begin{aligned}
& \text { تُخَلَّي الدَنْيَا عِيدْ.... }
\end{aligned}
$$

\section{شعر آدم فتحي/ موسيقى شوبان (Etudes.Op.10.No.3)/أداء لطفي بوشناق}

\section{أعود إليك}
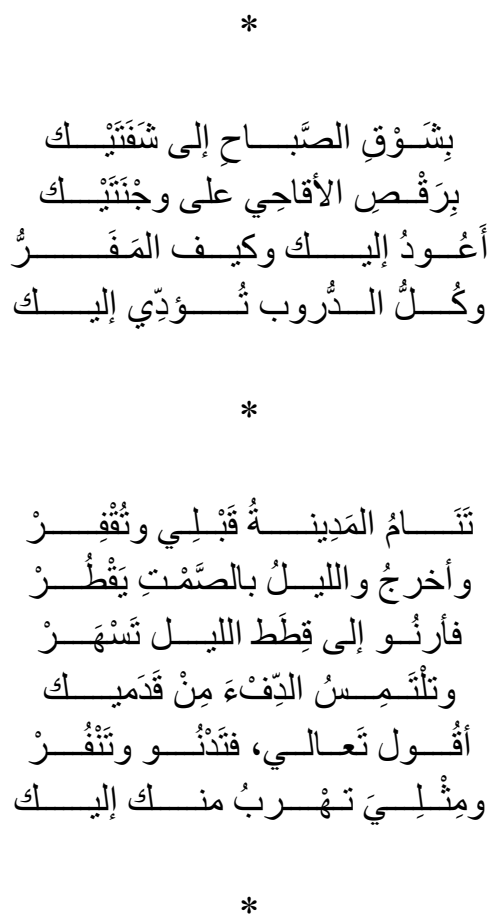


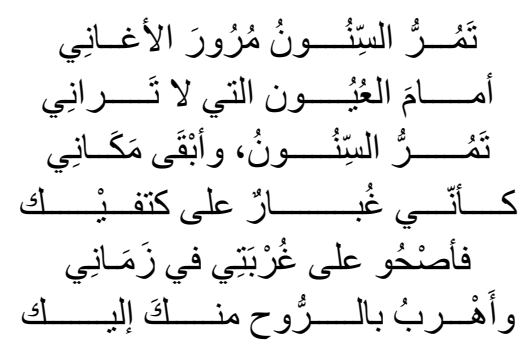

\section{شعر آدم فتحي/ تلحين لطفي بوشناق/ غناء علياء بلعيد}

\section{سآخذ وجهي وأرحل}

$$
\begin{aligned}
& * \\
& \text { سآخذ وجهي و أرحل إن أزفت ساعتي }
\end{aligned}
$$

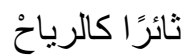

$$
\begin{aligned}
& \text { وملتهبًا كالحقول التي أشعلتها الجر اخْاخ } \\
& \text { سآخذ وجهي وأرحلْ سآخذ حزني وأرحلْ } \\
& \text { ملتحفًا بالأناثنيد و الذكرياتْ } \\
& \text { فاحفظو ا قربتي و عصايْ } \\
& \text { للصغير الذي سوف يكبر يومًا ويققو خُطايني } \\
& * \\
& \text { سآخذ وجهي وأرحلْ سآخذ حزني وأرحلْ } \\
& \text { لكنّني سأعُوذْ } \\
& \text { ومعي غضبٌ قاصفُ كالرُّ عُود } \\
& \text { ومعي خطوةٌ باتِّاع الؤجودْ } \\
& * \\
& \text { سآتي بوجهي و أرجع ممتطيًا صهوات النشيد } \\
& \text { قائلاً للطُّيُوْز }
\end{aligned}
$$

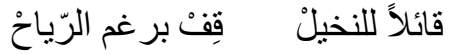

$$
\begin{aligned}
& \text { قائلاً للزياتين للبرتقال الوليذ }
\end{aligned}
$$

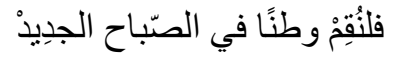

$$
\begin{aligned}
& \text { فلنُقِمِ وطنًا في الصنّباح الجدِيدْ... }
\end{aligned}
$$

شعر آدم فتحي/تلحين نبراس شمّام/غناء آمال الحمروني وعبير شمّام (البحث الموسيقيّ بقابس) 